\title{
EMPLOYEES MOTIVATION AND OPENNESS FOR CONTINUOUS IMPROVEMENT: COMPARATIVE STUDY IN POLISH AND JAPANESE COMPANIES
}

\author{
Dorota Stadnicka $^{1}$, Kozo Sakano ${ }^{2}$ \\ ${ }^{1}$ Rzeszow University of Technology, Faculty of Mechanical Engineering and Aeronautics, Poland \\ 2 Process Improvement Japan, Nagoya, Japan \\ Corresponding author: \\ Dorota Stadnicka \\ Rzeszow University of Technology \\ Faculty of Mechanical Engineering and Aeronautics \\ Al. Powstańców Warszawy 12, 35-959 Rzeszów, Poland \\ phone: (+48) 17 865-14-52 \\ e-mail: dorota.stadnicka@prz.edu.pl
}

Received: 27 May 2016

Accepted: 10 April 2017

\begin{abstract}
Currently, companies must change and evolve to keep pace with the changing environment, customers' requirements and to be better than their competitors. The changes result from the need to adapt the products to new customers' requirements as well as to maintain competitive prices of their products. Therefore, companies should be flexible to guarantee short lead time and minimalize their costs to offer a good price for the customers. At the same time, companies should create good work environment for their employees in order to get them involved in improvement processes. In order to survive and develop companies should motivate and involve their employees into a continuous improvement process in different areas of the company. Unfortunately, as based on the companies' practice and previous research, in many cases employees are not willing to engage in the company development. Continuous improvement is the basis of the philosophy of Quality Management and Lean Manufacturing, which come from Toyota Production System (TPS). The TPS eventually spread throughout the world, and it is held up as an example of the proper management of a production system. The assumptions of TPS system were used to build systems in other companies, but not always with the same success as it was in Toyota. For this reason, the authors of this paper seek to answer the question of whether there are differences in engagement in a continuous improvement process between employees in a Japanese company and a Polish company operating in the same industry and realizing the similar manufacturing. In order to verify this, the research was conducted in two manufacturing companies which operate in the automotive industry. The results of the study and their analysis are presented in the work.
\end{abstract}

KEYWORDS

continuous improvement, motivation, changes.

\section{Introduction}

Continuous improvement is the basis of company development. Companies have to make changes in products, technologies or work organization to adapt to the changing environmental conditions as well as to clients' requirements. It is important to engage all the company employees in the process of continuous improvement on their own work stands. This is related to the work they perform because they know what problems exist there and they can propose some useful improvements appropriately. The proposed improvements can concern work organization (better work organization can save time), used tools (better adapted tools can improve performance), process (better process performance can improve products quality), hazard protection (better protection can decrease the number of accidents), 
ways to avoid possible failures (better environmental protection), etc. It is only the matter of an adequate motivation system to encourage employees to propose improvements. However, first of all, companies expect their employees to perform their work properly, and only then they may propose improvements. In many cases, managers don't want employees to do anything apart from doing their tasks properly, because they think that development is a domain of engineers not workers. Therefore, in some cases, also managers have to be convinced to engage workers in continuous improvements.

Continuous improvement has been adopted in many companies, unfortunately not always with success. That is reported in publications [1-3]. Therefore, companies are looking for different possibilities to overcome the improvement failures [4] for example by implementation of Toyota Kata [5] (method proposed by Mike Rother), i.e. by "the systematic pursuit of desired conditions by utilizing human capabilities in a concerted way" [6].

Companies working under Toyota Production System have been successful in engaging their employees in discovering problems as well as in reporting mistakes what leads to the improvements implementation. Companies in Poland also try to develop similar motivation systems with different kinds of incentives but they are not so successful.

In the present study, the authors aim at discovering the differences in the engagement in a continuous improvement process between the employees working in Japan in a Japanese company and those in Poland in a Polish company. Both companies operate in an automotive sector and they are large companies. Both of them are production companies and they have implemented Lean Manufacturing system. What's more, both of them have an incentive system to encourage their employees to engage in continuous improvement.

The results of the conducted study are presented and discussed in this paper.

\section{Background}

In order to ensure the employees' involvement in continuous improvement the companies build different kinds of incentive systems based on the employees' needs and expectations. Maslow [7], in his theory of human motivation, says that a person can feel the following groups of needs which appear one by one just when the first one is met the next appears: the 'physiological' needs, the safety needs, the love needs, the esteem needs and the need for self-actualization. It depends on which level of needs an employee is, then different motivators may have a bigger influence on his or her behavior. However, there are such motivators which motivate all employees in the same way, e.g. in the work [8] author indicates that if the employees have an opportunity to contribute in the development of safe work procedures they are more likely to follow these procedures after their implementation and, additionally, they encourage other employees to do the same. This creates the safety culture and the employee's engagement is related to the level of the employees' involvement in their work processes. The effectiveness of a safety management system depends on the levels of safety-focused cognitive and emotional worker's engagement [9].

In the works [10-12], the authors present enablers and inhibitors concerning continuous improvement. The following should be listed among others: management involvement, the management of the continuous improvement processes, motivation of the workers, setting the objective for continuous improvement and measuring the results, building the culture of continuous improvement in the company, resources for continuous improvement, cross-functional teams and methodology for sustaining continuous improvement similar to TPS.

On the basis of the experience of the highly successful in continuous improvement companies, the authors of the work [13] indicate the mechanisms behind an employee's motivation which concern, among others, respect for people. Employees need to be meaningful and trusted, seen as individuals, be trained and educated as well as to gain authority and responsibility.

In the work [14] the authors also indicate that enriching work and giving a person more responsibility can motivate people.

The survey results presented in the work [15] provide that the most influential on how a person is engaged in continuous improvement is management engagement and understanding of company's goals as well as engaging people in goals setting. It is also important to support, explain the employees' suggestion prioritizing and invest in such improvement suggestions.

From the work [16] we conclude that continuous improvement is combined to form the Total Quality Management (TQM) practices. Hence, in a company all employees are responsible for the quality. Therefore, they should be involved in the quality improvement not only in assuring quality. In TQM, improvements mostly concern quality. In Lean Manufacturing concept improvements concern wastes. Poor quality is just one of the wastes [17]. Hence, employees should be motivated to identify also other kinds of 
wastes. Therefore, continuous improvement can concern for example performance improvement [5].

In the work [18] the authors e.g. show that engineers are mostly motivated by variable customer requirements. When a customer changes his or her requirements it forces taking such actions which will retain a customer by meeting his or her requirements. The possibility of loss (losing a customer) motivates people to take actions.

In Toyota, the employees are seen as a source of knowledge who accumulate the wisdom of experience [19]. That is why, we should use the opportunities and engage the employees in the continuous improvement process.

Based on the paper [20] it can be concluded that employees will engage more in continuous improvement when they are satisfied with the job and when they feel the job security. Therefore, creating friendly working environment as well as the continuous improvement culture is extremely important.

Companies use Kaizen events to engage employees in continuous improvement as a part of a crossfunctional team. Kaizen event is the basis for TPS [21]. The aim of Kaizen event is improving both processes and workers' efficiency [22, 23] and it can be implemented in any organization [24]. The research presented in the work [25] shows that to develop an employee's motivation in the engagement in continuous improvement by participating in events, strong management support during such events should be ensured.

In order to ensure the employees' engagement, the companies build different incentive systems and continuous improvement programs. Crucial areas of such a system are presented in the literature. The work [13] indicates communication, visualization and cross-functional and cross-professional improvement work as the most important areas. In the work [26] a structured approach to continual improvement is presented, and, as one of the main principles of the structured continual improvement, active participation of all organization staff in the continual process improvement is specified. A well-developed system can lead to sustainable development of the company. In the work [27] the authors propose a model for the sustainability assessment of the level of a work stand and of the whole company level. Such assessment can indicate possibilities for the further system development.

In the literature we can find the conclusion that to motivate people we have to use "a set of energetic forces that originate both within as well as beyond an individual's being, to initiate work-related behavior and to determine its form, direction, intensity, and duration" [28].

In the work [29] the authors indicate that the three theories presented in the literature dominate the motivation: goal-setting, social cognitive and organizational justice.

According to [30] employees are more motivated by tasks than by reward or punishment.

Work motivation should come from extrinsic and intrinsic issues although according to [31] better performance is obtained because of the intrinsic component, when an employee takes personal responsibility for his or her work and its quality.

According to Job Characteristics Model (JCM) [32], an employee assesses his or her job according to five dimensions: skill variety, task identity, task significance, autonomy and feedback.

In the lean manufacturing system we want to continually seek a possibility for wastes reduction [17] and we try to motivate employees to participate in the process of continuous improvement.

The implementation of the lean manufacturing results in limiting the autonomy defined by [33] as "the degree to which the job provides substantial freedom, independence, and discretion to the individual in scheduling the work and in determining the procedures to be used in carrying it out" due to the implemented improvements which results in short cycle times, and due to the standardization which results in repeatable work procedures. It can be the reason why employees are not willing to propose any improvements. They just don't see personal advantages.

In the game theory, the Nash equilibrium is a John Nash's solution concept [34, 35], which we can use in the continuous improvement system treating an organization as one player and an employee as another. An employee does what is the best for him or her in the situation when an organization has a certain system. Besides, the organization establishes a system which is the best for the organization in the situation when employees do what they do. It happens when an organization has different goals from employees, and when employees are not engaged in goals setting.

Because the employees' involvement in continuous improvement may reduce their freedom on their work stands, the workers may not be willing to involve themselves in creating improvements and implementing them. That is because only the company will benefit and not the workers.

De Treville and Antonakis [14] discovered that the lean production literature suggests three natural configurations of lean production: (a) feedback and 
task identity; (b) feedback, task identity, skill variety, and work facilitation; (c) feedback, task identity, skill variety, work facilitation, and responsible autonomy.

\section{Lean Manufacturing in Polish and Japanese companies}

The concept of Lean Manufacturing comes from Toyota Co. [36] which is a Japanese company, and which described the lean concept in TPS. That is why, the story of Lean Manufacturing in Japan is much longer than in Poland. First, lean manufacturing tools were implemented in Poland, in production companies which were branches of international or global enterprises operating in the automotive and aircraft industries (Table 1). After that, companies with Polish capital started the implementation of lean tools. Recently, more and more companies have been interested in Lean Manufacturing implementation.

Lean Manufacturing is based on continuous improvement and employees' engagement in the identification of opportunities in order to improve processes and products. The authors of this work were inter- ested in the possible differences between the employees' motivation and openness for changes in Japanese and Polish companies. The presented research was conducted as an attempt to answer the question concerning these differences.

The differences between Japanese, American and European companies were already a subject of research and are presented in the work [17]. Japanese companies with Japanese employees, Japanese companies with American employees, American companies with American employees and companies operating in Europe were compared (Table 2).

From Table 2 we can see that number of proposed improvements per an employee is higher in companies with Japanese employees, and number of training hours for employees is higher in the companies run by Japanese managers.

The situation of American and European companies is significantly different from the Japanese companies where Japanese employees work. The comparison of the Polish company (with Polish employees and Polish managers) with the Japanese company (with Japanese employees and Japanese managers) can provide the answer if after 25 years the situation has changed.

Table 1

Comparison of lean manufacturing tools first implementations in Japan and Poland.

\begin{tabular}{c|c|c|c|c}
\hline Country & Company & $\begin{array}{c}\text { Year of first lean tool } \\
\text { implementation }\end{array}$ & Capital & Source \\
\hline Japan & Toyota Co. & 1945 & Japanese & $($ Ohno, 1988) \\
\hline Poland & Delphi & 1998 & International & $($ Horbal et al., 2015) \\
\hline Poland & Pratt \& Whitney Rzeszów & 2003 & International & own research \\
\hline Poland & Stomil Sanok & 2007 & Majority Polish capital & own research \\
\hline Poland & Nowy Styl Group & 2011 & Entirely Polish capital & own research \\
\hline
\end{tabular}

Table 2

Comparison of Japanese, American and European companies for chosen indicators.

\begin{tabular}{l|c|c|c}
\hline & $\begin{array}{c}\text { Number } \\
\text { of proposed } \\
\text { improvements } \\
\text { per an employee }\end{array}$ & $\begin{array}{c}\text { Number } \\
\text { of training hours } \\
\text { for employees }\end{array}$ & 380.3 \\
\hline $\begin{array}{l}\text { Japanese companies with Japanese employees } \\
\text { and Japanese managers }\end{array}$ & 61.6 & 370.0 & 69.3 \\
\hline $\begin{array}{l}\text { Japanese companies with American employees } \\
\text { and Japanese managers }\end{array}$ & 1.4 & 46.4 & 71.3 \\
\hline $\begin{array}{l}\text { American companies with American employ- } \\
\text { ees and American managers }\end{array}$ & 0.4 & 173.3 & 17.3 \\
\hline Europe & 0.4 & 0.6 & \\
\hline
\end{tabular}




\section{Methodology}

This research was conducted in two manufacturing organizations which were non-randomly selected. What's more, several selection criteria (Table 3) were applied to increase the reliability and validity of the study results. The presented criteria were selected in order to eliminate the influence on the study results of the factors which, in the previous studies [37], were recognized as influencing the improvements implementation, forms of involvement in a continuous improvement process, employees engaged in problem solving or employees involved in a continuous improvement process. The characteristics of the companies are presented in Table 4.

The companies were initially identified by the contacts and partnerships, and they were asked whether they were willing to take a part in the re- search. Then, two companies which met the selection criteria were chosen.

The research were done with the use of a questionnaire which consisted of five parts.

The first and second parts of the survey concern the satisfaction about the work and the salary. The questions are presented in Tables 5 and 6 . For these questions Likert scale was applied as it is presented in Table 7.

The third part of the survey concerns the assessment of the employees' engagement in a development process. Multi choice questions are presented in Table 8 .

Next part of the questionnaire identifies the areas of engagement. Employees were asked to answer the questions whether they proposed any improvements concerning a certain area and whether these improvements were implemented (Table 9).

Table 3

Criteria of selection the companies.

\begin{tabular}{c|l|l}
\hline Criterion & \multicolumn{1}{c|}{ Description } & \multicolumn{1}{c}{ Purpose } \\
\hline Organization type & $\begin{array}{l}\text { The organizations participating in the re- } \\
\text { search should be manufacturers }\end{array}$ & $\begin{array}{l}\text { To assess involvement in production im- } \\
\text { provement }\end{array}$ \\
\hline Industry & $\begin{array}{l}\text { The organizations should operate in the } \\
\text { same industry }\end{array}$ & $\begin{array}{l}\text { To avoid differences coming from different } \\
\text { industries }\end{array}$ \\
\hline Lean Manufacturing System & $\begin{array}{l}\text { The organizations should have implement- } \\
\text { ed Lean Manufacturing System }\end{array}$ & $\begin{array}{l}\text { Because continuous improvement is the ba- } \\
\text { sis of Lean Manufacturing }\end{array}$ \\
\hline Size & $\begin{array}{l}\text { The organizations should be large organi- } \\
\text { zations }\end{array}$ & $\begin{array}{l}\text { Because in Poland it is easier to find a com- } \\
\text { pany with a Lean Manufacturing System } \\
\text { implemented among large companies }\end{array}$ \\
\hline Products & $\begin{array}{l}\text { The organizations should produce the sim- } \\
\text { ilar products }\end{array}$ & $\begin{array}{l}\text { To have similar processes and products to } \\
\text { improve }\end{array}$ \\
\hline Continuous improvement program & $\begin{array}{l}\text { The organizations should have implement- } \\
\text { ed continuous improvement program }\end{array}$ & $\begin{array}{l}\text { Because a program includes various ways } \\
\text { of employees' motivation to continuous im- } \\
\text { provement }\end{array}$ \\
\hline
\end{tabular}

Table 4

Characteristics of studied organizations.

\begin{tabular}{l|c|c}
\hline Description of the organization & Company PL & Company J \\
\hline Public/private & Private & Private \\
\hline Year founded & 1991 & 622 \\
\hline Capital & Entirely Polish capital & Majority Japanese capital \\
\hline Number of employees & 800 & 0.91 Euro* \\
\hline Cost of petrol & 0.94 Euro* & \\
\hline Monthly expenditure & & 60 years old \\
\hline Cost of food & & 4,284 EURO \\
\hline Indicators costs of living & 60 women & Yes \\
\hline Retirement age 2015 & 804 EURO & Yes \\
\hline Average salary in the company & Yes & Production \\
\hline Lean Manufacturing System & Yes & Large company \\
\hline Continuous improvement program & Production & Automotive \\
\hline Type of business & Large company & Automotive \\
\hline Size & & \\
\hline Industry & & \\
\hline
\end{tabular}

* DEC 2015 
Table 5

Questions concerning work satisfactions.

\begin{tabular}{l|l}
\hline No & \multicolumn{1}{|c}{ Question } \\
\hline Q1 & I am satisfied with my work position \\
\hline Q2 & I am satisfied with the work I perform \\
\hline Q3 & I am able to work harder if I receive higher salary \\
\hline Q4 & The company give me a possibility to self-realization in the work \\
\hline Q5 & In the work I can show an initiative \\
\hline Q6 & My supervisor treats me well \\
\hline Q7 & I am satisfied with my job \\
\hline
\end{tabular}

Table 6

Questions concerning satisfaction from the salary.

\begin{tabular}{c|l}
\hline No & \multicolumn{1}{|c}{ Question } \\
\hline Q8 & I am satisfied with my salary \\
\hline Q9 & Bonuses in my company are allocated equitably \\
\hline Q10 & I am satisfied with bonuses and rewards I receive \\
\hline Q11 & My work is appreciated by management \\
\hline Q12 & Praise and prizes are awarded equitably in my company \\
\hline
\end{tabular}

Table 7

Assessment scale

\begin{tabular}{l|c}
\hline \multicolumn{1}{c|}{ Explanation } & Value \\
\hline Agree strongly & 5 \\
\hline Agree moderately & 4 \\
\hline Difficult to say & 3 \\
\hline Disagree moderately & 2 \\
\hline Disagree strongly & 1 \\
\hline
\end{tabular}

Table 8

Questions concerning assessment of employees' engagement.

\begin{tabular}{c|l}
\hline No & \multicolumn{1}{c}{ Question } \\
\hline Q13 & Have you noticed in your workplace or department something that makes your work difficult? \\
\hline Q14 & Have you wondered about how you can improve the work on your work stand? \\
\hline Q15 & $\begin{array}{l}\text { Have you talked to someone about the problems you have noticed on your work stand? } \\
\text { (you can choose a few answers) }\end{array}$ \\
\hline Q16 & Were your ideas accepted and implemented? \\
\hline
\end{tabular}

Table 9

Questions concerning assessment of employees' engagement.

\begin{tabular}{c|l|l}
\hline No & \multicolumn{2}{|c}{ Question } \\
\hline \multirow{4}{*}{} & Have you ever proposed any solution concerning: \\
\cline { 2 - 3 } & IPQ & Improvement of product quality \\
\cline { 2 - 3 } & IWS & Improvement of work safety \\
\cline { 2 - 3 } & TSA & Time saving \\
\cline { 2 - 3 } & IPR & Improvement of productivity \\
\cline { 2 - 3 } & CRE & Costs reduction \\
\cline { 2 - 3 } & IER & Reduction of the negative influence on the environment \\
\cline { 2 - 3 } & IWO & Improvement of work organization \\
\hline Q18 & \multicolumn{2}{|l}{ Have the solutions proposed by you been implemented? } \\
\hline
\end{tabular}

They could give the following answers: yes many times, yes a few times, yes once, no. The last part concerns employees' motivation (Table 10). In this part, for each question possible answers were provided.
The questionnaires were distributed among the company workers working in a production area.

The collected questionnaires were statistically analyzed with the use of descriptive statistics. 
Table 10

Questions concerning motivation.

\begin{tabular}{c|l}
\hline No & \multicolumn{1}{c}{ Question } \\
\hline Q19 & How do often you propose improvements? \\
\hline Q20 & Do your supervisors encourage you to seek solutions that will facilitate and improve your work? \\
\hline Q21 & Do you accept proposals for changes in your workplace suggested by your superiors? \\
\hline Q22 & Do you want to participate in the implementation of the improvements? \\
\hline Q23 & $\begin{array}{l}\text { What motivates you the most to make improvements on your work stand and around it? } \\
\text { (choose max 3 options) }\end{array}$ \\
\hline Q24 & How many improvements did you propose last year? \\
\hline Q25 & How many of the improvements you proposed last year were implemented? \\
\hline Q26 & Has it been appreciated by the company? \\
\hline Q27 & The possibility of promotion in my company depends on (you can choose few answers) \\
\hline Q28 & Would you recommend working on this position to friend / colleague? \\
\hline
\end{tabular}

Then data were analyzed to find out if there were statistically justified differences between the answers of the Polish and Japanese employees. The analyses were conducted with the use of Chi-Square Tests in Minitab 16.

\section{Results of the study}

In total, 95 fulfilled questionnaires from the Japanese company (J-C) and 78 fulfilled questionnaires from the Polish companies (PL-C) were obtained. Tables 11-22 present the results. Not all questions were answered in all the questionnaires.

Tables 11-14 present answers concerning work satisfaction. It can be said that the employees in the Polish company are more satisfied with their work positions (PL-C: $69 \%$, J-C: 46\%) and with the work they perform (PL-C: $59 \%$, J-C: $43 \%$ ). $19 \%$ of the Polish employees don't want to work harder even if they receive a higher salary. At the same time, $52 \%$ of Polish employees and $56 \%$ of Japanese employees admit that they could work harder for a higher salary.

In the Polish company $44 \%$ of the employees admit that the company gives them a possibility for self-realization at work. In the Japanese company, it is only $31 \%$ of the employees.

$60 \%$ of the Polish employees and $30 \%$ of the Japanese employees are allowed to show initiative at work. In $82 \%$ cases in the Polish companies employees declare that they are treated well by a supervisor. In the Japanese companies it was $41 \%$ of employees. $77 \%$ of the Polish employees and $37 \%$ of the Japanese employees are satisfied with their jobs.

Table 11

Assessment of work satisfaction - PL-C.

\begin{tabular}{c|c|c|c|c|c}
\hline Question number & Mean & Median & Mode & Range & Interquartile Range \\
\hline Q1 & 4.01 & 4 & 5 & 4 & 2 \\
\hline Q2 & 3.75 & 4 & 4 & 4 & 2 \\
\hline Q3 & 3.43 & 4 & 4 & 4 & 1 \\
\hline Q4 & 3.11 & 3 & 3 & 4 & 1 \\
\hline Q5 & 3.70 & 4 & 4 & 4 & 2 \\
\hline Q6 & 4.33 & 5 & 5 & 4 & 1 \\
\hline Q7 & 4.03 & 4 & 4 & 4 & 1 \\
\hline
\end{tabular}

Table 12

Assessment of work satisfaction - J-C.

\begin{tabular}{c|c|c|c|c|c}
\hline Question number & Mean & Median & Mode & Range & Interquartile Range \\
\hline Q1 & 3.45 & 3 & 3 & 4 & 1 \\
\hline Q2 & 3.37 & 3 & 3 & 4 & 1 \\
\hline Q3 & 3.64 & 4 & 4 & 4 & 1 \\
\hline Q4 & 3.10 & 3 & 3 & 4 & 1 \\
\hline Q5 & 3.19 & 3 & 3 & 4 & 1 \\
\hline Q6 & 3.31 & 3 & 3 & 4 & 1 \\
\hline Q7 & 3.28 & 3 & 3 & 4 & 1 \\
\hline
\end{tabular}


Table 13

Assessment of work satisfaction - PL-C.

\begin{tabular}{c|c|c|c|c|c}
\hline \multirow{2}{*}{ Question number } & \multicolumn{5}{|c}{ Value } \\
\cline { 2 - 6 } & 5 & 4 & 3 & 2 & 1 \\
\hline \multirow{2}{*}{ Q1 } & 30 & 24 & 20 & 3 & 1 \\
\cline { 2 - 6 } & $38 \%$ & $31 \%$ & $26 \%$ & $4 \%$ & $1 \%$ \\
\hline \multirow{2}{*}{ Q2 } & 23 & 24 & 23 & 7 & 2 \\
\cline { 2 - 6 } & $29 \%$ & $30 \%$ & $29 \%$ & $9 \%$ & $3 \%$ \\
\hline \multirow{2}{*}{ Q3 } & 16 & 24 & 22 & 7 & 8 \\
\cline { 2 - 6 } & $21 \%$ & $31 \%$ & $29 \%$ & $9 \%$ & $10 \%$ \\
\hline \multirow{2}{*}{ Q4 } & 16 & 18 & 27 & 6 & 10 \\
\cline { 2 - 6 } & $21 \%$ & $23 \%$ & $35 \%$ & $8 \%$ & $13 \%$ \\
\hline \multirow{2}{*}{ Q5 } & 21 & 24 & 19 & 6 & 4 \\
\cline { 2 - 6 } & $28 \%$ & $32 \%$ & $26 \%$ & $8 \%$ & $5 \%$ \\
\hline \multirow{2}{*}{ Q6 } & 42 & 22 & 13 & 0 & 1 \\
\cline { 2 - 6 } & $54 \%$ & $28 \%$ & $17 \%$ & $0 \%$ & $1 \%$ \\
\hline \multirow{2}{*}{ Q7 } & 27 & 33 & 12 & 5 & 1 \\
\cline { 2 - 6 } & $35 \%$ & $42 \%$ & $15 \%$ & $6 \%$ & $1 \%$ \\
\hline
\end{tabular}

Table 14

Assessment of work satisfaction - J-C.

\begin{tabular}{c|c|c|c|c|c}
\hline \multirow{2}{*}{ Question number } & \multicolumn{5}{|c}{ Value } \\
\cline { 2 - 6 } & 5 & 4 & 3 & 2 & 1 \\
\hline \multirow{2}{*}{ Q1 } & 7 & 37 & 43 & 5 & 2 \\
\cline { 2 - 6 } & $7 \%$ & $39 \%$ & $46 \%$ & $5 \%$ & $2 \%$ \\
\hline \multirow{2}{*}{ Q2 } & 6 & 35 & 43 & 8 & 2 \\
\cline { 2 - 6 } & $6 \%$ & $37 \%$ & $46 \%$ & $9 \%$ & $2 \%$ \\
\hline \multirow{2}{*}{ Q3 } & 15 & 38 & 34 & 6 & 1 \\
\cline { 2 - 6 } & $16 \%$ & $40 \%$ & $36 \%$ & $6 \%$ & $1 \%$ \\
\hline \multirow{2}{*}{ Q4 } & 2 & 27 & 47 & 14 & 4 \\
\cline { 2 - 6 } & $2 \%$ & $29 \%$ & $50 \%$ & $15 \%$ & $4 \%$ \\
\hline \multirow{2}{*}{ Q5 } & 3 & 25 & 56 & 7 & 3 \\
\cline { 2 - 6 } & $3 \%$ & $27 \%$ & $60 \%$ & $7 \%$ & $3 \%$ \\
\hline \multirow{2}{*}{ Q6 } & 9 & 29 & 42 & 10 & 4 \\
\cline { 2 - 6 } & $10 \%$ & $31 \%$ & $45 \%$ & $11 \%$ & $4 \%$ \\
\cline { 2 - 6 } & 4 & 31 & 48 & 9 & 2 \\
\hline \multirow{2}{*}{ Q7 } & $4 \%$ & $33 \%$ & $51 \%$ & $10 \%$ & $2 \%$ \\
\hline
\end{tabular}

Tables $15-18$ present answers concerning satisfaction with the salary. We can say that $45 \%$ of the Polish employees and 19\% of the Japanese employees are not satisfied with a salary. $25 \%$ of the Polish employees and $17 \%$ of the Japanese employees think that bonuses in the company are not allocated equitably. Nevertheless, $36 \%$ of the Polish employees and
$37 \%$ of the Japanese employees are satisfied with the bonuses and rewards they receive. In the Japanese company $77 \%$ of the employees don't know if their work is appreciated by the management. In the Polish company $48 \%$ think that their work is appreciated by the management.

Table 15

Assessment of satisfaction with the salary - PL-C.

\begin{tabular}{c|c|c|c|c|c}
\hline Question number & Mean & Median & Mode & Range & Interquartile Range \\
\hline Q8 & 2.75 & 3 & 4 & 4 & 2 \\
\hline Q9 & 3.09 & 3 & 3 & 4 & 1.5 \\
\hline Q10 & 2.91 & 3 & 2 & 4 & 2 \\
\hline Q11 & 3.29 & 3 & 4 & 4 & 1 \\
\hline Q12 & 3.04 & 3 & 3 & 4 & 1 \\
\hline
\end{tabular}


Table 16

Assessment of satisfaction with the salary - J-C.

\begin{tabular}{c|c|c|c|c|c}
\hline Question number & Mean & Median & Mode & Range & Interquartile Range \\
\hline Q8 & 3.14 & 3 & 3 & 4 & 1 \\
\hline Q9 & 3.19 & 3 & 3 & 4 & 1 \\
\hline Q10 & 3.18 & 3 & 3 & 4 & 1 \\
\hline Q11 & 3.05 & 3 & 3 & 4 & 0 \\
\hline Q12 & 3.20 & 3 & 3 & 4 & 1 \\
\hline
\end{tabular}

Table 17

Assessment of satisfaction with the salary - PL-C.

\begin{tabular}{c|c|c|c|c|c}
\hline \multirow{2}{*}{ Question number } & \multicolumn{5}{|c}{ Value } \\
\cline { 2 - 6 } & 5 & 4 & 3 & 2 & 1 \\
\hline \multirow{2}{*}{ Q8 } & 4 & 22 & 16 & 19 & 15 \\
\cline { 2 - 6 } & $5 \%$ & $29 \%$ & $21 \%$ & $25 \%$ & $20 \%$ \\
\hline \multirow{2}{*}{ Q9 } & 11 & 13 & 34 & 10 & 9 \\
\cline { 2 - 6 } & $14 \%$ & $17 \%$ & $44 \%$ & $13 \%$ & $12 \%$ \\
\hline \multirow{2}{*}{ Q10 } & 9 & 18 & 18 & 19 & 12 \\
\cline { 2 - 6 } & $12 \%$ & $24 \%$ & $24 \%$ & $25 \%$ & $16 \%$ \\
\hline \multirow{2}{*}{ Q11 } & 11 & 26 & 22 & 8 & 9 \\
\cline { 2 - 6 } & $14 \%$ & $34 \%$ & $29 \%$ & $11 \%$ & $12 \%$ \\
\hline \multirow{2}{*}{ Q12 } & 4 & 25 & 31 & 6 & 12 \\
\cline { 2 - 6 } & $5 \%$ & $32 \%$ & $40 \%$ & $8 \%$ & $15 \%$ \\
\hline
\end{tabular}

Table 18

Assessment of satisfaction with the salary - J-C.

\begin{tabular}{c|c|c|c|c|c}
\hline \multirow{2}{*}{ Question number } & \multicolumn{5}{|c}{ Value } \\
\cline { 2 - 6 } & 5 & 4 & 3 & 2 & 1 \\
\hline \multirow{2}{*}{ Q8 } & 2 & 33 & 41 & 12 & 6 \\
\cline { 2 - 6 } & $2 \%$ & $35 \%$ & $44 \%$ & $13 \%$ & $6 \%$ \\
\hline \multirow{2}{*}{ Q9 } & 3 & 32 & 43 & 12 & 4 \\
\cline { 2 - 6 } & $3 \%$ & $34 \%$ & $46 \%$ & $13 \%$ & $4 \%$ \\
\hline \multirow{2}{*}{ Q10 } & 3 & 32 & 42 & 13 & 4 \\
\cline { 2 - 6 } & $3 \%$ & $34 \%$ & $45 \%$ & $14 \%$ & $4 \%$ \\
\hline \multirow{2}{*}{ Q11 } & 1 & 14 & 72 & 3 & 4 \\
\cline { 2 - 6 } & $1 \%$ & $15 \%$ & $77 \%$ & $3 \%$ & $4 \%$ \\
\hline \multirow{2}{*}{ Q12 } & 1 & 29 & 55 & 6 & 3 \\
\cline { 2 - 6 } & $1 \%$ & $31 \%$ & $59 \%$ & $6 \%$ & $3 \%$ \\
\hline
\end{tabular}

In the Japanese company $9 \%$ of the employees think that praise and prizes are awarded not equitably. In the Polish company it is $23 \%$ of the employees.

Table 19 presents answers concerning the assessment of the employees' engagement. In $93 \%$ of the questionnaires Japanese employees answered that they notice there is something that makes their work difficult at their work place or department, and they think how they could improve their work place (97\%). In about half of the cases Polish employees don't think about what bothers them at work, but in $79 \%$ of the cases they think what could be improved.
In the Japanese companies $94 \%$ employees talk about the noticed problems with colleagues, $47 \%$ with supervisors, while in the Polish companies it is correspondingly $39 \%$ and $42 \%$.

$76 \%$ of the Japanese employees and only $4 \%$ of the Polish employees said that their ideas were fully accepted and implemented.

Tables 20 and 21 present answers concerning the assessment of the areas of engagement. Most of the proposed improvements in the Polish companies concern the quality of products and work organization, the least proposed improvements concern the reduction of the negative influence on the environment and productivity. 
Management and Production Engineering Review

Table 19

Assessment of employees' engagement.

\begin{tabular}{c|l|c|c|c|c}
\hline \multirow{2}{*}{ Answer } & \multicolumn{2}{|c}{ PL-C } & \multicolumn{2}{c}{ J-C } \\
\cline { 3 - 6 } & & Frequency & $\%$ & Frequency & $\%$ \\
\hline \multirow{2}{*}{ Q13 } & Yes & 40 & $51 \%$ & 88 & $93 \%$ \\
\cline { 2 - 6 } & No & 38 & $49 \%$ & 7 & $7 \%$ \\
\hline \multirow{2}{*}{ Q14 } & Yes & 62 & $79 \%$ & 92 & $97 \%$ \\
\cline { 2 - 6 } & No & 16 & $21 \%$ & 3 & $4 \%$ \\
\hline \multirow{5}{*}{ Q15 } & Yes, I have talked to a colleague & 35 & $39 \%$ & 66 & $94 \%$ \\
\cline { 2 - 6 } & Yes, I have talked to my superior & 37 & $42 \%$ & 64 & $47 \%$ \\
\cline { 2 - 6 } & No, because I haven't noticed any problems & 14 & $16 \%$ & 4 & $3 \%$ \\
\cline { 2 - 6 } & No, because ... & 3 & $3 \%$ & 1 & $1 \%$ \\
\hline \multirow{5}{*}{ Q16 } & No, it was impossible to implement & 12 & $17 \%$ & 5 & $5 \%$ \\
\cline { 2 - 6 } & No, my superior decided that the problem is not so important & 13 & $19 \%$ & 8 & $8 \%$ \\
\cline { 2 - 6 } & No, because it would require too large expenses & 7 & $10 \%$ & 0 & $0 \%$ \\
\cline { 2 - 6 } & No, we had no time to do it & 10 & $14 \%$ & 5 & $5 \%$ \\
\cline { 2 - 6 } & Yes, partially & 24 & $35 \%$ & 5 & $5 \%$ \\
\cline { 2 - 6 } & Yes, as a whole & 3 & $4 \%$ & 72 & $76 \%$ \\
\hline
\end{tabular}

Table 20

Assessment of areas of engagement - PL-C (Q17, Q18).

\begin{tabular}{|c|c|c|c|c|c|}
\hline \multicolumn{2}{|c|}{ Area } & $\begin{array}{c}\text { Yes, } \\
\text { many times }\end{array}$ & $\begin{array}{c}\text { Yes, } \\
\text { few times }\end{array}$ & $\begin{array}{l}\text { Yes, } \\
\text { once }\end{array}$ & No \\
\hline \multirow{4}{*}{ IPQ } & \multirow{2}{*}{$\mathrm{P}$} & 25 & 31 & 6 & 15 \\
\hline & & $32 \%$ & $40 \%$ & $8 \%$ & $19 \%$ \\
\hline & \multirow{2}{*}{$\mathrm{I}$} & 9 & 13 & 12 & 32 \\
\hline & & $14 \%$ & $20 \%$ & $18 \%$ & $48 \%$ \\
\hline \multirow{4}{*}{ IWS } & \multirow{2}{*}{$\mathrm{P}$} & 16 & 14 & 18 & 29 \\
\hline & & $21 \%$ & $18 \%$ & $23 \%$ & $38 \%$ \\
\hline & \multirow{2}{*}{ I } & 2 & 11 & 11 & 35 \\
\hline & & $3 \%$ & $19 \%$ & $19 \%$ & $59 \%$ \\
\hline \multirow{4}{*}{ TSA } & \multirow{2}{*}{$\mathrm{P}$} & 16 & 19 & 13 & 28 \\
\hline & & $21 \%$ & $25 \%$ & $17 \%$ & $37 \%$ \\
\hline & \multirow{2}{*}{$\mathrm{I}$} & 6 & 7 & 18 & 27 \\
\hline & & $10 \%$ & $12 \%$ & $31 \%$ & $47 \%$ \\
\hline \multirow{4}{*}{ IPR } & \multirow{2}{*}{$\mathrm{P}$} & 12 & 15 & 13 & 35 \\
\hline & & $16 \%$ & $20 \%$ & $17 \%$ & $47 \%$ \\
\hline & \multirow{2}{*}{$\mathrm{I}$} & 8 & 13 & 9 & 25 \\
\hline & & $15 \%$ & $24 \%$ & $16 \%$ & $45 \%$ \\
\hline \multirow{4}{*}{ CRE } & \multirow{2}{*}{$\mathrm{P}$} & 10 & 19 & 21 & 23 \\
\hline & & $14 \%$ & $26 \%$ & $29 \%$ & $32 \%$ \\
\hline & \multirow{2}{*}{$\mathrm{I}$} & 5 & 11 & 17 & 25 \\
\hline & & $9 \%$ & $19 \%$ & $29 \%$ & $43 \%$ \\
\hline \multirow{4}{*}{ IER } & \multirow{2}{*}{$\mathrm{P}$} & 9 & 9 & 11 & 47 \\
\hline & & $12 \%$ & $12 \%$ & $14 \%$ & $62 \%$ \\
\hline & \multirow{2}{*}{$\mathrm{I}$} & 3 & 5 & 10 & 36 \\
\hline & & $6 \%$ & $9 \%$ & $19 \%$ & $67 \%$ \\
\hline \multirow{4}{*}{ IWO } & \multirow{2}{*}{$\mathrm{P}$} & 18 & 18 & 17 & 22 \\
\hline & & $24 \%$ & $24 \%$ & $23 \%$ & $29 \%$ \\
\hline & \multirow{2}{*}{$\mathrm{I}$} & 9 & 11 & 15 & 24 \\
\hline & & $15 \%$ & $19 \%$ & $25 \%$ & $41 \%$ \\
\hline
\end{tabular}

Table 21

Assessment of areas of engagement - J-C (Q17, Q18).

\begin{tabular}{|c|c|c|c|c|c|}
\hline \multicolumn{2}{|c|}{ Area } & $\begin{array}{c}\text { Yes, } \\
\text { many times }\end{array}$ & $\begin{array}{c}\text { Yes, } \\
\text { few times }\end{array}$ & $\begin{array}{l}\text { Yes, } \\
\text { once }\end{array}$ & No \\
\hline \multirow{4}{*}{ IPQ } & \multirow{2}{*}{$\mathrm{P}$} & 17 & 62 & 9 & 7 \\
\hline & & $18 \%$ & $65 \%$ & $9 \%$ & $7 \%$ \\
\hline & \multirow{2}{*}{ I } & 10 & 63 & 11 & 11 \\
\hline & & $11 \%$ & $66 \%$ & $12 \%$ & $12 \%$ \\
\hline \multirow{4}{*}{ IWS } & \multirow{2}{*}{$\mathrm{P}$} & 18 & 51 & 15 & 11 \\
\hline & & $19 \%$ & $54 \%$ & $16 \%$ & $12 \%$ \\
\hline & \multirow{2}{*}{ I } & 11 & 48 & 17 & 19 \\
\hline & & $12 \%$ & $51 \%$ & $18 \%$ & $20 \%$ \\
\hline \multirow{4}{*}{ TSA } & \multirow{2}{*}{$\mathrm{P}$} & 11 & 55 & 9 & 20 \\
\hline & & $12 \%$ & $58 \%$ & $9 \%$ & $21 \%$ \\
\hline & \multirow{2}{*}{ I } & 6 & 55 & 12 & 22 \\
\hline & & $6 \%$ & $58 \%$ & $13 \%$ & $23 \%$ \\
\hline \multirow{4}{*}{ IPR } & \multirow{2}{*}{$\mathrm{P}$} & 12 & 60 & 11 & 12 \\
\hline & & $13 \%$ & $63 \%$ & $12 \%$ & $13 \%$ \\
\hline & \multirow{2}{*}{ I } & 8 & 51 & 18 & 18 \\
\hline & & $8 \%$ & $54 \%$ & $19 \%$ & $19 \%$ \\
\hline \multirow{4}{*}{ CRE } & \multirow{2}{*}{$\mathrm{P}$} & 5 & 24 & 9 & 57 \\
\hline & & $5 \%$ & $25 \%$ & $9 \%$ & $60 \%$ \\
\hline & \multirow{2}{*}{$\mathrm{I}$} & 3 & 18 & 10 & 64 \\
\hline & & $3 \%$ & $19 \%$ & $11 \%$ & $67 \%$ \\
\hline \multirow{4}{*}{ IER } & \multirow{2}{*}{$\mathrm{P}$} & 4 & 21 & 13 & 57 \\
\hline & & $4 \%$ & $22 \%$ & $14 \%$ & $60 \%$ \\
\hline & \multirow{2}{*}{ I } & 2 & 17 & 15 & 61 \\
\hline & & $2 \%$ & $18 \%$ & $16 \%$ & $64 \%$ \\
\hline \multirow{4}{*}{ IWO } & \multirow{2}{*}{$\mathrm{P}$} & 3 & 17 & 12 & 63 \\
\hline & & $3 \%$ & $18 \%$ & $13 \%$ & $66 \%$ \\
\hline & \multirow{2}{*}{ I } & 1 & 13 & 12 & 69 \\
\hline & & $1 \%$ & $14 \%$ & $13 \%$ & $73 \%$ \\
\hline
\end{tabular}

$\mathrm{P}$ - proposed solutions, I - implemented solutions 
Table 22

Assessment of motivations.

\begin{tabular}{|c|c|c|c|c|c|}
\hline & \multirow{2}{*}{ Answer } & \multicolumn{2}{|c|}{ PL-C } & \multicolumn{2}{|c|}{$\mathrm{J}-\mathrm{C}$} \\
\hline & & Frequency & $\%$ & Frequency & $\%$ \\
\hline \multirow{6}{*}{ Q19 } & Always when I see the possibility for improvements & 32 & $42 \%$ & 10 & $11 \%$ \\
\hline & Rather often & 6 & $8 \%$ & 10 & $11 \%$ \\
\hline & Not so often & 10 & $13 \%$ & 44 & $46 \%$ \\
\hline & Rarely & 11 & $14 \%$ & 19 & $20 \%$ \\
\hline & Very rarely & 12 & $16 \%$ & 9 & $9 \%$ \\
\hline & Never & 5 & $7 \%$ & 3 & $3 \%$ \\
\hline \multirow{6}{*}{ Q20 } & Always & 26 & $35 \%$ & 6 & $6 \%$ \\
\hline & Rather often & 17 & $23 \%$ & 17 & $18 \%$ \\
\hline & Not so often & 10 & $13 \%$ & 44 & $46 \%$ \\
\hline & Rarely & 11 & $15 \%$ & 19 & $20 \%$ \\
\hline & Very rarely & 6 & $8 \%$ & 7 & $7 \%$ \\
\hline & Never & 5 & $7 \%$ & 2 & $2 \%$ \\
\hline \multirow{5}{*}{ Q21 } & I accept them & 38 & $53 \%$ & 49 & $52 \%$ \\
\hline & I accept them, but I propose how to develop them & 18 & $25 \%$ & 22 & $23 \%$ \\
\hline & I accept them, but they are usually wrong & 6 & $8 \%$ & 14 & $15 \%$ \\
\hline & Sometimes, I don't accept them & 7 & $10 \%$ & 9 & $9 \%$ \\
\hline & I don't accept them & 3 & $4 \%$ & 0 & $0 \%$ \\
\hline \multirow{3}{*}{ Q22 } & Yes & 56 & $75 \%$ & 51 & $54 \%$ \\
\hline & I don't know & 19 & $25 \%$ & 41 & $43 \%$ \\
\hline & No & 0 & $0 \%$ & 2 & $2 \%$ \\
\hline \multirow{7}{*}{ Q23 } & Prizes & 14 & $20 \%$ & 55 & $58 \%$ \\
\hline & Cash Rewards & 60 & $87 \%$ & 29 & $31 \%$ \\
\hline & Prizes from management & 20 & $29 \%$ & 18 & $19 \%$ \\
\hline & Possibility to work overtime & 7 & $10 \%$ & 10 & $11 \%$ \\
\hline & Promotion & 20 & $29 \%$ & 16 & $17 \%$ \\
\hline & Possibility to participate in trainings & 19 & $28 \%$ & 6 & $6 \%$ \\
\hline & Other & 1 & $1 \%$ & 10 & $11 \%$ \\
\hline \multirow{4}{*}{ Q24 } & $>12$ & 3 & $5 \%$ & 5 & $5 \%$ \\
\hline & $6-12$ & 5 & $8 \%$ & 39 & $41 \%$ \\
\hline & $<6$ & 30 & $47 \%$ & 43 & $45 \%$ \\
\hline & I haven't propose anything & 26 & $41 \%$ & 8 & $8 \%$ \\
\hline \multirow{5}{*}{ Q25 } & the all & 1 & $2 \%$ & 0 & $0 \%$ \\
\hline & $>12$ & 5 & $8 \%$ & 1 & $1 \%$ \\
\hline & $6-12$ & 0 & $0 \%$ & 13 & $14 \%$ \\
\hline & $<6$ & 25 & $40 \%$ & 65 & $68 \%$ \\
\hline & None of these improvements was implemented & 31 & $50 \%$ & 16 & $17 \%$ \\
\hline \multirow{2}{*}{ Q26 } & Yes & 21 & $34 \%$ & 43 & $45 \%$ \\
\hline & No & 41 & $66 \%$ & 52 & $55 \%$ \\
\hline \multirow{6}{*}{ Q27 } & Workload & 2 & $3 \%$ & 2 & $2 \%$ \\
\hline & Work quality & 24 & $31 \%$ & 52 & $55 \%$ \\
\hline & Professional experience & 20 & $26 \%$ & 53 & $56 \%$ \\
\hline & There are no such possibilities & 8 & $10 \%$ & 11 & $12 \%$ \\
\hline & Connections & 24 & $31 \%$ & 18 & $19 \%$ \\
\hline & Other & 0 & $0 \%$ & 1 & $1 \%$ \\
\hline \multirow{3}{*}{ Q28 } & Yes & 28 & $39 \%$ & 19 & $20 \%$ \\
\hline & No & 13 & $18 \%$ & 19 & $20 \%$ \\
\hline & Difficult to say & 31 & $43 \%$ & 57 & $60 \%$ \\
\hline
\end{tabular}


Management and Production Engineering Review

At the same time, in the Japanese companies, the most often proposed are the improvements concerning quality of products and work safety, while the improvements concerning work organization and costs reduction are the least likely proposed.

In the Polish companies the solution concerning work organization and cost reduction is the most often implemented, and the least common improvements concern reduction of the negative influence on the environment and work safety. At the same time, in Japanese companies the improvements concerning product quality, work safety and productivity are the most often implemented, and work organization and costs reduction are the least likely to be implemented solutions.

Table 22 presents the answers concerning the assessment of motivations. Assessing the employees' motivation it can be said that $42 \%$ Polish employees say they propose improvements always when they see the possibility, while $46 \%$ Japanese employees consider that they propose improvements not so often.

The Polish employees say (35\%) that the supervisors encourage them to seek solutions that will facilitate and improve their work, while $46 \%$ of the Japanese employees say that it happens not so often. Similarly the Polish and Japanese employees admitted that they accept proposals for changes from their supervisors.

Higher percentage of the Polish employees (75\%) wants to participate in the implementation of improvements comparing to the Japanese employees (54\%).

For the Polish employees the biggest incentives are cash rewards (87\%). For the Japanese employees they are prizes $(58 \%)$.

Most Polish employees (88\%) proposed during the last year less than 6 or didn't propose any improvements, while $86 \%$ of the Japanese employees proposed from 1 to 12 improvements. $66 \%$ Polish employees and $55 \%$ Japanese employees said that it was not appreciated by the company.

Mostly Japanese employees indicated professional experience $(56 \%)$ and work quality $(55 \%)$ as a main reason for promotion in the company, whereas in the Polish companies employees indicated mostly work quality (31\%) and connections (31\%), and then professional experience $(26 \%)$.

Finally, $39 \%$ of the Polish employees and $20 \%$ of the Japanese employees would recommend working on his or her position to a friend/colleague.

\section{Data analysis}

The gathered data were additionally analyzed to find statistically justified differences between the Polish and Japanese employees' answers. The results of this analysis are presented in Tables 23 and 24 .

Table 23

Chi-square analysis results.

\begin{tabular}{c|c|c|c}
\hline Question number & Chi-Sq & DF & P-value \\
\hline Q1 & 25.026 & 4 & 0.000 \\
\hline Q2 & 16.971 & 4 & 0.002 \\
\hline Q3 & 9.692 & 4 & 0.046 \\
\hline Q4 & 22.397 & 4 & 0.000 \\
\hline Q5 & 30.038 & 4 & 0.000 \\
\hline Q7 & 48.335 & 4 & 0.000 \\
\hline Q8 & 39.053 & 4 & 0.000 \\
\hline Q9 & 17.560 & 4 & 0.002 \\
\hline Q10 & 14.201 & 4 & 0.007 \\
\hline Q11 & 19.963 & 4 & 0.001 \\
\hline Q12 & 41,282 & 4 & 0.000 \\
\hline Q13 & 12,817 & 4 & 0.012 \\
\hline Q14 & 38.052 & 1 & 0.000 \\
\hline Q15 & 13.196 & 1 & 0.000 \\
\hline Q16 & 86.726 & 5 & 0.000 \\
\hline Q17 & 28.698 & 6 & 0.000 \\
\hline Q18 & 30.870 & 6 & 0.000 \\
\hline Q19 & 35.318 & 5 & 0.000 \\
\hline Q20 & 35.542 & 5 & 0.000 \\
\hline Q21 & 5.420 & 4 & 0.247 \\
\hline Q22 & 6.639 & 1 & 0.010 \\
\hline Q23 & 50.337 & 6 & 0.000 \\
\hline Q24 & 33.860 & 3 & 0.000 \\
\hline Q25 & 18.623 & 1 & 0.000 \\
\hline Q26 & 2.016 & 1 & 0.156 \\
\hline Q27 & 11.705 & 4 & 0.020 \\
\hline Q28 & 7.505 & 2 & 0.023 \\
\hline & & & \\
\hline & & 0.002 \\
\hline Q 14 \\
\hline
\end{tabular}

Table 24

Chi-square analysis results.

\begin{tabular}{c|c|c|c}
\hline Question number & Chi-Sq & DF & P-value \\
\hline IPQ & 13.632 & 3 & 0.003 \\
\hline IWS & 27.975 & 3 & 0.000 \\
\hline TSA & 18.619 & 3 & 0.000 \\
\hline IPR & 36.575 & 3 & 0.000 \\
\hline CRE & 18.942 & 3 & 0.000 \\
\hline IER & 5.812 & 3 & 0.121 \\
\hline TWO & 29.436 & 3 & 0.000 \\
\hline
\end{tabular}


On the basis of the calculated $\mathrm{P}$-value it can be said that there are no significant differences, only in some cases, when we consider the acceptance of proposals for changes made by supervisors (Q21) and when the appreciation of the employees' efforts is considered (Q26).

There are also no significant differences in the number of proposed improvements concerning the reduction of the negative influence on the environment (Table 24).

In the Polish company $62 \%$ of the employees and in the Japanese company $60 \%$ of the employees admitted that during the last year they hadn't proposed any improvement concerning the reduction of a negative influence on the environment.

Other answers show significant differences in work satisfaction, satisfaction with salary, employees' engagement and the areas of this engagement.

\section{Continuous improvement program in Polish company}

In the studied Polish company a Continuous Improvement Program (CIP) was established. According to the program each employee can submit an idea using a special form which is freely accessible in a paper and in an electronic version in each department. An individual employee or a group of employees (max 5 people) can submit a proposal. The proposal should be threw into a suggestion box. Each week all the proposals are removed from the box and, if at least two ideas were in the box, a coordinator of CIP in the department can organize a meeting of the Committee to evaluate the proposals. The Committee assesses the ideas according to the assessment criteria. An employee who submitted an idea is informed about the committee decision no later than one month.

The committee consists of a lean manager, director of the department, quality management system representative, process engineer, head of quality control, head of maintenance services and Health and Safety specialist. The coordinator can ask other people to attend the meeting depending on the assessed proposals.

The Committee uses the following assessment criteria to assess the proposals which should:

- be in accordance with the company policy,

- be possible to implement in practice,

- possibly give financial benefits,

- involve costs which are possible to be incurred,

- not worsen the safety of workers.

A proposal can be rejected if:
- improving one activity it simultaneously aggravates other,

- it is assessed by a specialist as impossible to implement,

- it concerns a new machine,

- it concerns a reported failure,

- it has been proposed as a corrective action for a reported nonconformity or client's claim.

A proposal can obtain max 10 points which can be multiplied by a coefficient depending on the real financial benefits. The coefficient equals 1 if it is impossible to calculate financial benefits. If the benefits are less than 120 EURO, the coefficient equals 2. If the benefits are more than 11,900 EURO, the coefficient equals 10. For other amounts the coefficients are as it is presented in Table 25 .

Table 25

Coefficients for financial benefits.

\begin{tabular}{c|c}
\hline Financial benefits EURO & Coefficient \\
\hline No countable & 1 \\
\hline$<120$ & 2 \\
\hline$<240$ & 3 \\
\hline$<590$ & 4 \\
\hline$<1.190$ & 5 \\
\hline$<1.790$ & 6 \\
\hline$<2.380$ & 7 \\
\hline$<5.950$ & 8 \\
\hline$<11.900$ & 9 \\
\hline$>11.900$ & 10
\end{tabular}

If a proposal was submitted by a few employees, the number of points which one employee obtains is multiplied by another coefficient, e.g. if two employees submitted a proposal and this proposal was assessed for 6 points each of them gets 5 points (see Table 26).

Table 26

Coefficients depending on number of employees in a team.

\begin{tabular}{c|c}
\hline Number of employees & Coefficient \\
\hline 1 & 1 \\
\hline 2 & 0.8 \\
\hline 3 & 0.7 \\
\hline 4 & 0.6 \\
\hline 5 & 0.5 \\
\hline
\end{tabular}

Each employee who submitted a proposal is informed about the results of the assessment. The proposals get a certain number of points depending of the assessment results and, simultaneously, each employee who submitted an idea gets a certain number of points. 
After an employee collects at least 25 points, he or she receives a financial reward. Rules for receiving a reward are presented in Table 27.

Table 27

Values of rewards.

\begin{tabular}{c|c}
\hline Number of points & Value of reward [EURO] \\
\hline 25 & 50 \\
\hline 50 & 60 \\
\hline 75 & 70 \\
\hline 100 & 80 \\
\hline
\end{tabular}

Every 6 months the Committee can also award a prize for two best proposals. Therefore, an employee can additionally get 240 EURO.

Rewards are given after the implementation and positive verification of ideas.

The average salary of an employee in the region is about 830 EURO [38]. Therefore, the award which is 80 EURO equals to about $10 \%$ of the employee's salary.

Financial awards are the main motivators in the company.

\section{Continuous improvement program in Japanese company and employees' situation}

Continuous improvement program realized in the Japanese company is directly connected with Hoshin Kari (policy deployment). Every year each employee has to declare a target. At the beginning of the year, each person has to present the results of his or her work. During the year the progress is also monitored and at the end of the year the target achievement is checked. If the target is achieved, an employee gets an annual bonus. The kind of effect the activities undertaken by an employee caused is also analyzed even if the goal hasn't been achieved. The performance is reflected by the bonus. What's more, an employee obtains a small reward. It is about 100-500 JPY. Employees get summer and winter bonuses which can be 1-2 mln JPY. The amount is decided according to seniority and performance.

There are periodical meetings and presentation in the company, especially for new employees. They have to prepare a presentation on a problem and propose a solution for the problem. The use of the statistical quality control (SQC) is emphasized in the company to be applied in the problems analysis.

Meetings concerning each workstation are organized. Kaizen is the key. There are also morning meetings. If there is a problem they gather and iden- tify the cause of a problem, then countermeasures and proposals for improvements are suggested.

When a defective product appears a brain storming is done. Workers are involved in the problems analysis.

Therefore, it can be said that financial awards are not an incentive for employees in the Japanese company. That is a system and culture which motivate employees to continuous improvement. Proposing improvements is a duty of each employee. They propose improvements not to obtain financial awards but to perform their duties well.

The employees have many privileges. They obtain subsidy to transportation, gas, lunch, etc. Each year an employee obtains 500 points, which he or she can use for food in a cafeteria, gas, travelling, etc. 500 points equals 50,000 JPY (about 400 EURO). The employees can also get accommodation for a single or married person. Besides, the company offers houses for employees. The company has also a recreation facility in the mountains and at the seaside as well as a gym for the employees to use.

Employees have 10 days off for the New Year and, additionally, 20 days of paid holiday leave called a golden week. When an employee wants to buy a car or a house he or she can borrow money from the company. The company also offers education for employees, mostly technical and language education.

\section{Discussion}

On the basis of the performed studies it can be concluded that there are certainly many differences between the results of the survey obtained from the Polish and Japanese companies. The authors have analyzed the possible reasons of these differences. First, an overall situation in each country was analyzed on the basis of basic indicators. Next, the cultural differences were discussed.

In 2014 the population of Poland was 38,011,735 while in Japan it was $127,131,800$ [39]. There is an important difference in the level of growth rate of GDP in Poland (3.6 percent change) and Japan (0.5 percent change) (data for 2015) [39]. In 2015 the level of GDP per capita in Poland was 12495 USD and in Japan it was 32486 USD [39]. The unemployment level in 2015 in Poland was $7.5 \%$ and in Japan $3.4 \%$ [39], even when manufacturing production increased by $6.2 \%$ in Poland and decreased $2.1 \%$ in Japan in December of 2015 against the same corresponding month in the previous year. Figure 1 presents data comparison for Polish and Japan manufacturing production for the period of March-December 2015. Generally, manufacturing production in Poland was 
increasing while in Japan it was decreasing over the analyzed period of time [40].

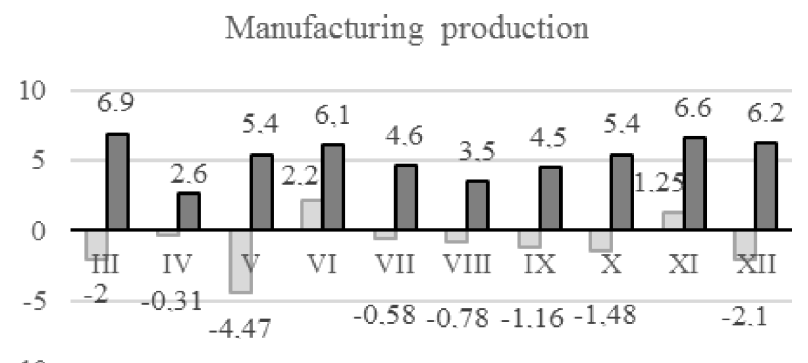

$-10$

\section{$\square$ Japan $\square$ Poland}

Fig. 1. Manufacturing production changes in Poland and Japan [40].

Average monthly per capita expenditures of the households in Poland equal to 1,079 PLN [41] that is about 245 EURO, and in Japan they are 623,439 JPY, that is about 5,050 EURO [42]. An average salary in a Polish company is 804 Euro while in Japanese companies it is 4,284 Euro. On the basis of the presented economic analysis it can be said that for the employees implementing improvements in a Japanese company it can be a way of sustaining manufacturing companies in the country because workforce is expensive. There, the employees earn much more than the employees of a Polish company, however the average amount is not so impressive when compared to average expenditures of households.

With regard to the culture of both countries it may be concluded that Japanese employees are attached to their company very much. In Japan, there is no respect for people who change work often. Therefore, an employee has to work for the respect of managers and supervisors performing work in the best way and performing the duties almost perfectly. While in Poland it is not odd when a person wants to change an employer. Polish employees have no problem with looking for work abroad, while a very few Japanese employees work outside the country. Therefore, the employees' mobility in Poland is much higher than in Japan. In Poland the continuous improvement systems, such as the one analyzed in this study, are something new and it needs much attention from managers and supervisors to motivate people to engage in continuous improvement. However, in the Japanese company continuous improvement is a part of work. The only question is how they should propose improvement but this derives from the company policy. The targets which are established for each employee derive from the policy deployment (Hoshin Kanri). Therefore, achieving a target is a main reason for all proposed improvements. At the same time, in the Polish company a continuous improvement system is still something existing besides the company targets. Employees still learn that the proposed improvement can help in achieving the targets.

\section{Conclusions}

The presented studies show the comparison between Polish and Japanese companies operating in the same industry. In the paper, the details about a continuous improvement system in the Polish company, which motivates employees to make suggestions for improvements, are presented. In the Japanese company the system of rewarding employees concerns the whole work performance and the proposals of improvement are just a small part of what is taken into consideration when deciding on the amount of bonuses.

Continuous improvement is a part of organizational culture in the Japanese company while in the Polish company it is still hard work to motivate people to engage in the processes development.

In general, employees in the Polish company are more satisfied with work and less satisfied with the salary than the Japanese company employee. It is difficult to be justified because taking into consideration the salaries and average expenditures of households in both countries, Japanese employees should rather be the dissatisfied ones.

Much higher engagement in a continuous process can be noticed in the Japanese company. However, supervisors in the Polish companies motivate workers more than the supervisors in the Japanese company. Additionally, it is worth emphasizing that most Polish employees are motivated by cash rewards while the Japanese employees are motivated by prizes.

\section{Limitations and future research}

In the present study the authors investigated only the companies in the automotive industry. Therefore, the results may not be true about other industries. Moreover, in other companies operating in the automotive industry in Japan as well as in Poland, the situation can be different. Therefore, the conclusions cannot be applied to all companies operating in the automotive industry neither in Poland nor in Japan.

It would be interesting to perform further research in other European countries as well as in developing countries. 
The authors would like to thank the companies for agreeing to conduct the survey among their employees.

\section{References}

[1] Horbal R., Kagan R., Koch T., Sobczyk T., Last 10 years of Lean in Poland. Conclusions and perspectives [in Polish], Available in: lean.org.pl, 27.10 .2015

[2] Rapp C., Eklund J., Sustainable development of improvement activities: the long-term operation of a suggestion scheme in a Swedish company, Total Quality Management, 13, 7, 945-969, 2002.

[3] Terziovski M., Sohal A.S., The adoption of continuous improvement and innovation strategies in Australian manufacturing firms, Technovation, 20, 539550, 2000.

[4] Chih Wei Wu, Chyong Ling Chen, A new focus on overcoming the improvement failure, Technovation 24, 585-591, 2004.

[5] Carvalho J-D, Ratnayake R.M.C., Stadnicka D., Sousa R., Isoherranen J.V., Kumar M., Performance Enhancing in the Manufacturing Industry: An Improvement KATA Application, IEEE International Conference on Industrial Engineering and Engineering Management (IEEM2016), 4-7.12.2016, Bali, Indonesia, 2016.

[6] Rother M., Toyota Kata: Managing People for Improvement, Adaptiveness and Superior Results, McGraw-Hill, 2009.

[7] Maslow A., A theory of human motivation, Psychological Review, 50, 370-396, 1943, Retrieved June 2001, from http://psychclassics.yorku.ca/ Maslow/motivation.htm.

[8] Lockwood N., Leveraging employee engagement for competitive advantage: HR's strategic role, HR Magazine, 52, 3, 1-11, 1997.

[9] Wachter J.K., Yorio P.L., A system of safety management practices and worker engagement for reducing and preventing accidents: An empirical and theoretical investigation, Accident Analysis and Prevention, 68, 117-130, 2014.

[10] Bateman N., Sustainability: the elusive element of process improvement, International Journal of Operations \& Production Management, 25, 3-4, 261276, 2005.

[11] Bateman N., Rich N., Companies' perceptions of inhibitors and enablers for process improvement activities, International Journal of Operations \& Production Management, 23, 2, 185-199, 2003.
[12] Garcia-Sabater Julio J., Marin-Garcia Juan A., Can we still talk about continuous improvement? Rethinking enablers and inhibitors for successful implementation, Int. J. Technology Management, 55, 1/2, 28-42, 2011.

[13] Swartling D., Poksinska B., Management Initiation of Continuous Improvement from a Motivational Perspective, Journal of Applied Economics and Business Research, 3, 2, 81-94, 2013.

[14] De Treville S., Antonakis J., Could lean production job design be intrinsically motivating? Contextual, configurational, and levels-of-analysis issues, Journal of Operations Management, 24, 99-123, 2006.

[15] Holtskog H., Continuous Improvement beyond the Lean understanding, Procedia CIRP 7, 575-579, 2013.

[16] Shah R., Ward P.T., Lean manufacturing: context, practice bundles, and performance, Journal of Operations Management, 21, 129-149, 2003.

[17] Womack J.P., Jones D.T., Roos D., The Machine that Changed the World, Harper Collins Publishers, New York, 1990.

[18] Ringen G., Holtskog H., How enablers for lean product development motivate engineers, International Journal of Computer Integrated Manufacturing, 26, 12, 1117-1127, Special Issue: SI, 2013.

[19] Takeuchi H., Osono E., Shimizu N., The contradictions that drive Toyota's success, Harvard Business Review, June, 96-104, 2008.

[20] Marinova S.V., Peng C., Lorinkovac N., Van Dyne L., Chiaburu D., Change-oriented behavior: A metaanalysis of individual and job design predictors, Journal of Vocational Behavior, 88, 104-120, 2015.

[21] Anh P.C., Jing Z., Matsui Y., Empirical study on transferability of Kaizen practices, The 11th International DSI and the 16th APDSI Joint Meeting, Taipei, Taiwan, July 12-16, 2011.

[22] Brunet A.P., New S., Kaizen in Japan: An Empirical Study, International Journal of Operations and Production Management, 23, 12, 1426-1446, 2003.

[23] Venkataiah C., Sagi S., Relationship between kaizen event and perceived quality performance in Indian automobile industry, International Journal of Management and Business Studies, 2, 2231-2463, 2012.

[24] Doolen T., Van Aken E., Farris J., Worley J., Huwe J., Kaizen events and organizational performance: a field study, International Journal of Productivity \& Performance Management, 57, 8, 637-58, 2008.

[25] Farris J.A., Van Aken E.M., Doolen T.L., Worley J., Critical success factors for human resource 
outcomes in Kaizen events: an empirical study, Int. J. Production Economics, 117, 42-65, 2009.

[26] IAEA-TECDOC-1491: Management of continual improvement for facilities and activities: a structured approach, IAEA International Atomic Energy Agency, Vienna, April 2006.

[27] Bateman N., David A., Process improvement programmes: a model for assessing sustainability, International Journal of Operations and Production Management, 22, 5, 515-526, 2002.

[28] Pinder C.C., Work Motivation in Organizational Behavior. Upper Saddle River, NJ: Prentice Hall, 1998.

[29] Latham G.P., Pinder C.C., Work motivation theory and research at the dawn of the twenty-first century, Annu. Rev. Psychol., 56, 485-516, 2005.

[30] Brief A.P., Aldag R.J., The intrinsic-extrinsic dichotomy: Toward conceptual clarity, Academy of Management Review 2, 3, 496-500, 1977.

[31] Hackman J.R., Lawler E.E., Employee reactions to job characteristics, Journal of Applied Psychology, 55, 3, 259-286, 1971.

[32] Hackman J.R., Oldham G.R., Motivation through the design of work: test of a theory, Organization- al Behavior and Human Performance, 16, 250-279, 1976.

[33] Hackman J.R., Oldham G.R., Work Redesign, Addison-Wesley, Reading, MA, 1980.

[34] Nash J., Equilibrium points in n-person games, Proceedings of the National Academy of Sciences, 36, 1, 48-49, 1950.

[35] Nash J., Non-Cooperative Games, The Annals of Mathematics, 54, 2, 286-295, 1951.

[36] Ohno T., Toyota Production System: Beyond LargeScale Production, Cambridge: Productivity Press, 1988.

[37] Stadnicka D., Antosz K., Continuous improvement practice in large enterprises: study results, Int. J. Qual. Res., 9, 1, 9-26, 2015.

[38] Statement on the socio-economic situation in the region of Podkarpackie, Statistical Office in Rzeszow, 28.08.2015.

[39] https://knoema.com

[40] http://www.tradingeconomics.com/japan/gdp-growth

[41] Situation of households in 2014 in the light of the results of household budgets studies, Available in Polish in: http://stat.gov.pl/, Dec. 2015.

[42] http://grading.jpn.org/ 